\title{
SELF-ESTEEM, PERCEIVED SELF-EFFICACY, CONSUMPTION OF TOBACCO AND ALCOHOL IN SECONDARY STUDENTS FROM URBAN AND RURAL AREAS OF MONTERREY, NUEVO LEÓN, MÉXICO
}

\author{
Raúl Martínez Maldonado ${ }^{1}$ \\ Luiz Jorge Pedrão ${ }^{2}$ \\ María Magdalena Alonso Castillo ${ }^{3}$ \\ Karla Selene López García ${ }^{3}$ \\ Nora Nely Oliva Rodríguez ${ }^{3}$
}

Martínez Maldonado R, Pedrão LJ, Alonso Castillo MM, López García KS, Oliva Rodríguez NN. Self-esteem, perceived self-efficacy, consumption of tobacco and alcohol in secondary students from urban and rural areas of Monterrey, Nuevo León, México. Rev Latino-am Enfermagem 2008 maio-junho; 16(especial):614-20

This study aimed to know the differences, if any, in the consumption of tobacco and alcohol among adolescents from urban and rural areas, and if self-esteem and self-efficacy are related to the consumption in these two groups of adolescents from secondary schools in urban and rural areas of Nuevo León México, from January to June in 2006. The study was based on the theoretical concepts of self-esteem, perceived selfefficacy and consumption of alcohol and tobacco. The design was descriptive and correlational with a sample of 359 students. A substantial difference was found in the consumption of tobacco among secondary students from urban and rural areas $(U=7513.50, p=.03)$. The average consumption in urban area was higher $(\bar{\chi}=$ $.35)$ than in the rural area $(\bar{\chi}=.14)$. A negative and significant relation was found between the quantity of drinks consumed on a typical day and self-esteem $\left(r_{s}=-.23, p<.001\right)$, as well as for the quantity of cigarettes consumed on a typical day $\left(r_{s}=-.20, p<.001\right)$.

DESCRIPTORS: self-concept; efficacy; tobacco; alcohol drinking; education primary and secondary

\section{AUTOESTIMA, AUTOEFICACIA PERCIBIDA, CONSUMO DE TABACO Y ALCOHOL EN ESTUDIANTES DE EDUCACIÓN SECUNDARIA DE ÁREA URBANA Y RURAL DE MONTERREY, NUEVO LEÓN, MÉXICO}

El propósito del estudio fue conocer si existen diferencias en el consumo de tabaco y alcohol en adolescentes del área urbana y rural y si la autoestima y la autoeficacia se relacionan con el consumo en estos dos grupos de adolescentes que estudian en la educación secundaria en el área urbana y rural de Nuevo León México, entre enero y junio de 2006. El estudio se realizó bajo los conceptos teóricos de autoestima, autoeficacia percibida y consumo de alcohol y tabaco. El diseño fue descriptivo y correlacional. La muestra fue de 359 estudiantes. Se encontró diferencia significativa de consumo de tabaco en estudiantes de secundaria urbana y rural ( $U=7513.50, p=.03)$ siendo más alta la media de consumo en área urbana ( $\bar{\chi}=.35)$ que en la rural $(\bar{\chi}=.14)$. Se encontró relación negativa y significativa de cantidad de bebidas consumidas en un día típico y la autoestima $\left(r_{s}=-.23, p<.001\right)$, así mismo de la cantidad de cigarrillos consumidos en un día típico $\left(r_{s}=-.20, p<.001\right)$.

DESCRIPTORES: autoimagen; eficacia; tabaco; consumo de bebidas alcólicas; educación primaria y secundaria

\section{AUTO-ESTIMA, AUTO-EFICÁCIA PERCEBIDA, CONSUMO DE TABACO E ÁLCOOL ENTRE ESTUDANTES DO ENSINO FUNDAMENTAL, DAS ÁREAS URBANA E RURAL, DE MONTERREY, NUEVO LEÓN, MÉXICO}

O propósito deste estudo foi verificar diferenças no consumo de tabaco e álcool entre adolescentes das áreas urbana e rural, e se a auto-estima e auto-eficácia se relacionam com o consumo nestes dois grupos de adolescentes do ensino fundamental nas áreas urbana e rural de Nuevo León México, entre janeiro e junho de 2006. Este estudo, descritivo e correlacional, se baseou nos conceitos teóricos de auto-estima, autoeficácia percebida e consumo de álcool e tabaco. A mostra foi de 359 estudantes. Encontrou-se diferença significativa de consumo de tabaco entre estudantes do ensino fundamental, áreas urbana e rural, $(U=7513.50$, $p=.03)$ sendo mais alta a média de consumo em área urbana $(\bar{\chi}=.35)$ que na rural $(\bar{\chi}=.14)$. Encontrou-se relação, negativa e significativa, entre quantidade de bebidas consumidas num dia típico e a auto-estima ( $r_{s}=-$ $.23, p<.001)$, assim como da quantidade de cigarros consumidos num dia típico $\left(r_{s}=-.20, p<.001\right)$.

DESCRITORES: auto-imagem; eficácia; tabaco; consumo de bebidas alcoólicas; educação primária e secundária

${ }^{1}$ Faculty, School of Nursing, Autonomous University of Nuevo León, México, e-mail: ramartinez_14@yahoo.com.mx; ${ }^{2}$ Faculty, University of São Paulo at Ribeirão Preto, College of Nursing, WHO Collaborating Centre for Nursing Research Development, Brazil, e-mail: lujope@eerp.usp.br; ${ }^{3}$ Faculty, participant of the Academic Group for Addiction Prevention, Autonomous University of de Nuevo León, México, School of Nursing 


\section{INTRODUCTION}

In recent years, adolescents' and preadolescents' consumption of addictive substances, such as alcohol and tobacco, has been defined as a research priority in the health area. This is due to its direct or indirect association to some of the main causes of death among adolescents and young people in the period from 1990 to 2002. Among these causes, accidents occupy the first place, followed by homicides and injuries caused by other people, while suicides and self-inflicted injuries rank fourth. Moreover, this initial consumption may be a factor of multiple social consequences, low performance at school, school drop-out, aggressive behavior and family difficulties ${ }^{(1)}$.

Epidemiological literature points out that adolescents and young people are more vulnerable to the use of alcohol and tobacco. Approximately one out of three adolescents is affected by the consumption of these substances ${ }^{(2)}$. Besides, adolescents underestimate the consequences for health, even when the effects from the use of alcohol and tobacco are responsible for three of the ten main causes of preventable deaths in Mexico $^{(3)}$

Previous studies indicate that the consumption of alcohol and tobacco starts during adolescence and results from an interaction of personal (adolescents' characteristics), social (environment) and interpersonal (parents and partners) factors ${ }^{(4)}$. Substance use, like any other behavior, is learned through a modeling process of imitation and reinforcement, in its relation with the social and cultural environment ${ }^{(5)}$.

Very clear laws in Mexico demand the indication of consequences on the labels of alcohol and tobacco products for sale, and have imposed publicity sanctions and restrictions on sales of those products to minors. However, despite all this effort, the early start of alcohol and tobacco use during adolescence is still increasing, in line with research carried out among secondary students, which found a significant increase in tobacco use by adolescents. In $1989,44.8 \%$ of the students had already smoked at least once in their lives, against $48.2 \%$ in $1993^{(6)}$. The last National Research of Addictions (Encuesta Nacional de Adicciones) in Mexico ${ }^{(7)}$ showed a significant increase in the use of tobacco by the national population. It reported that 10.1 and $6.1 \%$ of the urban and rural population were active smokers, corresponding to almost a million people. Among these students, $43.8 \%$ of the male and $43.7 \%$ of the female adolescents started smoking when they were 11 to 14 years old, and one out of ten male adolescents consumed tobacco before the age of 11 years.

Some studies indicate that sociocultural factors influence the beginning and continuous use of alcohol and tobacco by adolescents ${ }^{(8)}$. The Mexican Official Legislation (Norma Oficial Mexicana) for the Prevention, Treatment and Control of Addictions (NOM028-SSA2, 1999) ${ }^{(9)}$ rules that there are protection factors in which social abilities like self-esteem, refusal and social competence may eliminate, decrease or neutralize the risk of starting or continuing the use of alcohol and tobacco.

Studies have admitted the need to study individual social abilities, such as self-esteem ${ }^{(10)}$ and perceived self-efficacy ${ }^{(11)}$, as predictors for facing and resisting the use of addictive substances. Perceived self-efficacy and self-esteem contribute to the ability of adolescents to resist pressure from the social environment (friends, colleagues) to use tobacco or alcohol. People build these abilities according to their environment and their relation with their family, friends and partners. It is hypothesized that there are differences in these two social abilities between students living and studying in urban and rural areas, due to contextual differences.

From the authors' personal experience in community practice, there is a significant increase in the consumption of alcohol and tobacco by adolescents who are admitted to and take secondary education in urban areas, getting involved in abuse behaviors faster. On the other hand, there are few studies on this theme regarding adolescents from rural areas and, therefore, it is considered important to know if there are differences in alcohol and tobacco consumption in these two groups of secondary-school adolescents from urban and rural areas of Nuevo León, México.

The guiding concepts of this study are perceived self-efficacy ${ }^{(5)}$ and self-esteem ${ }^{(10)}$, as well as alcohol and tobacco consumption. For self-efficacy, this study considered the confidence in being able to control the use of alcohol and tobacco, which increases the probability of either drinking or smoking moderately, or not drinking or smoking in risk situations. Besides, self-efficacy is defined as the belief in one's own ability to organize and execute actions required to handle future situations. Self-efficacy perceptions exert direct influence on decisions to be 
made. High self-efficacy allows subjects to be more confident in their own abilities, while people who present low self-efficacy are likely to doubt their abilities ${ }^{(12)}$.

On the other hand, one of the most important functions of self-esteem is to control behavior in the face of a self-evaluation process, so that adolescents' behavior is highly determined by the self-esteem they have at that moment ${ }^{(10)}$ Selfesteem is defined as one's consideration or regard for oneself, based on thoughts, feelings, sensations and experiences gathered in life. A good level of self-esteem is considered a protection factor that isolates the subject from harmful influences, as these people are more vulnerable to antisocial behavior ${ }^{(13)}$.

From another point of view, when personal self-esteem is threatened by a negative event, it produces an increase in anxiety levels, which happens because the subject reacts by searching for other alternatives to face the situation. In many cases, those alternatives lead to not very appropriate or harmful ways, considering one's health, such as the consumption of tobacco, alcohol and other drugs ${ }^{(14)}$.

According to the latter, the following purposes were proposed for the study: 1) identify if there are differences in the consumption of tobacco and alcohol by urban and rural secondary-school students; 2) determine the relation between selfesteem and tobacco and alcohol consumption by students in urban and rural secondary schools; 3) determine the relation between perceived selfefficacy and tobacco and alcohol consumption by students in urban and rural secondary schools; 4) identify the differences in self-esteem and perceived self-efficacy betweenstudents from urban and rural secondary schools.

\section{METHODS}

The present study had a descriptivecorrelational design, as the aspects of a situation were observed, described and documented exactly as they happen. Variables of self-esteem and perceived self-efficacy were then associated with the use of tobacco and alcohol.
The study population consisted of 862 students, from both genders, who were taking the first, second and third grade in two secondary public schools (morning groups). One of the schools was situated in the city and the other in the rural area of Monterrey - Nuevo León, México, from January to June 2006.

The sample was probabilistic, stratified by proportional allocation into twelve strata that correspond to combinations of school grades and gender. The size of the study sample was obtained through Query Advisor 4.0 software. The study considered a $95 \%$ confidence level, with .80 of power, for a correlation of .20. The sample consisted of 359 participants (303 students from the urban area and 56 from the rural area).

The present study used a questionnaire, requesting information regarding personal data and consumption of tobacco and alcohol by the subject (Cedula de Datos Personales y de Consumo de Tabaco y Alcohol - CDPCTA), and two instruments: the Self-Consistency Scale - $\operatorname{SCS}^{(10)}$ and the SelfEfficacy Scale to resist to the consumption of alcohol and tobacco ${ }^{(15)}$.

The questionnaire about personal data and consumption of tobacco and alcohol consists of 16 reactors, which correspond to four questions regarding socio-demographic and socio-cultural data. The reactors about the consumption of alcohol and tobacco consist of 12 questions, six of them for tobacco and the other six for alcohol. The questions about alcohol consumption asked about the initial age of alcohol consumption, consumption at least once in life, frequency and quantity of standard drinks consumed on a typical day, in the last thirty days and in the last few days. Likewise, the questions about tobacco comprehended the initial age of tobacco consumption, tobacco consumption at least once in the lifetime, frequency and quantity of cigarettes consumed on a typical day, in the last thirty days and in the last few days.

The Self-Consistency Scale $(\text { SCS })^{(10)}$ presents 27 questions that measure self-esteem and stability of self-conception. Answer scores vary from 1 to 4 , in which 1 means never, 2 rarely, 3 sometimes and 4 always. The scale reached a Cronbach's Alpha of .89 in the Cronbach's Alpha in young people from North America. 
The self-efficacy instrument to resist to the consumption of alcohol and tobacco, is a result of the Situational Confidence Questionnaire (SCQ) ${ }^{(15)}$, which measures Perceived Self-Efficacy as confidence to resist to the temptation of drinking alcohol. The questionnaire was designed for people who present heavy consumption of alcohol and its author reports a score of .98 on the Cronbach's Alpha test.

This study considered what is established by the Regulation of the Health General Law for Matters of Health Research (Reglamento de la Ley General de Salud en Materia de Investigación para la Salud Secretaria de Salubridad y Asistencia) ${ }^{(16)}$. Based on the Article 14 Paragraph VII, the study relied on the favorable ruling of the Ethics and Research Commission from the Nursing University of UANL (Comisiones de Ética y de Investigación de la Facultad de Enfermería de la UANL) for its application.

Descriptive statistics was used for data analysis, with frequencies, proportions, central tendency and variability measures. The calculation of the rates led to the internal consistency of the instruments through Cronbach's Alpha coefficient. The normality test was applied, in order to get to inferential statistics through the Kolmogorov-Smirnov test. The use of non-parametric tests was then decided, according to the normality of data distribution.

The following tests were considered to respond to the objectives: Mann-Whitney U-test for the first objective and Spearman's Correlation Coefficients for the second and third, according to the results of the normality test. Mann-Whitney's Utest was also used for the fourth objective.

\section{RESULTS}

Regarding the socio-demographic characteristics of the secondary students, $52.1 \%$ of the students from the urban area were female, while $53.6 \%$ from the rural area were male. Most students were taking the first grade of secondary school, with $36 \%$ in the urban area and $35.7 \%$ in the rural area, corresponding to the established sample criteria. Considering occupation, only $6.6 \%$ of the students from the city and $21.4 \%$ from the rural area study and work. The occupation as an employee or assistant predominated, with $4.3 \%$ in the urban and $21.4 \%$ in the rural area (Table 1 ).
Table 1 - Socio-demographic characteristics of secondary students

\begin{tabular}{lcccc}
\hline \multicolumn{1}{c}{ Variable } & \multicolumn{2}{c}{ Rural Area } & \multicolumn{2}{c}{ Urban Area } \\
& $\boldsymbol{f}$ & $\%$ & $\boldsymbol{f}$ & $\%$ \\
\hline Gender & & & & \\
Male & 30 & 53.6 & 145 & 47.9 \\
$\quad$ Female & 26 & 46.4 & 158 & 52.1 \\
School Level & & & & \\
First Grade & 20 & 35.7 & 109 & 36.0 \\
$\quad$ Second Grade & 19 & 33.9 & 92 & 30.4 \\
$\quad$ Third Grade & 17 & 30.4 & 102 & 33.7 \\
Occupation & & & & \\
$\quad$ Study & 44 & 78.6 & 283 & 93.4 \\
$\quad$ Study and Work & 12 & 21.4 & 20 & 6.6 \\
If the person works, what & & & & \\
does he/she do? & & & & \\
$\quad$ Does not work & 44 & 78.6 & 283 & 93.4 \\
$\quad$ Employee or assistant & 12 & 21.4 & 13 & 4.3 \\
Packager & - & - & 7 & 2.3 \\
\hline
\end{tabular}

Source: $(C D P)$

$n=359$

The average age of the students was 13 years in the urban and rural areas. Students who consumed alcohol presented an average age of 11.85 years $(S D=1.82)$ to start consumption in the rural and 11.89 $(S D=1.79)$ in the urban area. The quantity of drinks on a typical day was $1.15(S D=0.38)$ in the rural area and $2.19(S D=2.62)$ in the city. Tobacco consumption presented an average age of 12.33 years $(S D=0.58)$ to start consumption in the rural and $12.58(S D=1.59)$ in the urban area. The average quantity of tobacco consumed in the rural area was $2.67(S D=1.53)$ and in the city $2.06(S D=1.39)$.

Table 2 - Mann-Whitney U- Test of alcohol and tobacco consumption in students by school type

\begin{tabular}{lcccccc}
\hline School & \multicolumn{2}{l}{ Rural Area } & Urban Area & $\begin{array}{c}\text { Mann- } \\
\text { Whitney's U }\end{array}$ & P-value \\
& $\bar{\chi}$ & Mdn & $\bar{\chi}$ & Mdn & & \\
\hline Tobacco & .14 & .00 & .35 & .00 & 7513.50 & .03 \\
Alcohol & 27 & .00 & .41 & .00 & 8168.50 & .52 \\
\hline \multicolumn{2}{l}{ Source: (CDP) } & & & & &
\end{tabular}

$n=359$

The results from Table 2 respond to the first study objective, in which the alcohol and tobacco consumption is observed by school type. It shows that there are significant differences in tobacco consumption depending on the school type ( $U=$ 7513.500, $p=.03$ ), with the highest consumption of 
those substances occurring in secondary schools from the urban area. The study also found that students from the urban area who consume alcohol, present higher grades. Nevertheless, this difference is not statistically significant.

Table 3 is presented to respond to the second objective, which is to determine the relation between self-esteem and the use of alcohol and tobacco by students from urban and rural secondary schools.

Table 3 - Spearman Correlation of self-consistency (self-esteem) rates with the quantity of alcohol and tobacco consumed by secondary students from urban and rural areas

\begin{tabular}{cc}
\hline Variable & Self-Consistency \\
\hline Quantity of alcohol consumed on a typical day & $-.23^{* *}$ \\
Quantity of cigarettes consumed on a typical day & $-.20^{\star *}$
\end{tabular}

Source: SCS

** $\mathrm{p}<.001$

$n=359$

Table 3 indicates Spearman's Correlation coefficient between the continuous study variables, which showed a negative and significant association between the quantity of standard drinks consumed on a typical day and self-consistency (self-esteem). Likewise, a significant and negative relation was reported for the quantity of cigarettes consumed on a typical day. In other words, the lower self-consistency or self-esteem, the higher the quantity of cigarettes and standard alcoholic drinks consumed on a typical day, in students from both rural and urban areas.

Table 4 below responds to the third objective, which is to determine the relation between Perceived Self-Efficacy and alcohol and tobacco consumption by students from urban and rural secondary schools.

Table 4 - Spearman Correlation between perceived self-efficacy rates and quantity of alcohol and tobacco consumed by secondary students from urban and rural areas

\begin{tabular}{lc}
\hline \multicolumn{1}{c}{ Variable } & $\begin{array}{c}\text { Perceived } \\
\text { Self-Efficacy }\end{array}$ \\
\hline Quantity of alcohol consumed on a typical day & .01 \\
Quantity of cigarettes consumed on a typical day & -.03 \\
\hline Source: SCA & \\
$* * p<.001$ & \\
$n=359$ &
\end{tabular}

According to Table 4, the continuous study variables have not indicated a significant association between the quantities of standard drinks consumed or cigarettes smoked on a typical day, and perceived self-efficacy in the secondary students. Finally, Table 5 identifies the differences inself-esteem and perceived self-efficacy between students from urban and rural secondary schools. These data respond to the fourth objective.

Table 5 - Mann-Whitney U-Test of self-consistency and perceived self-efficacy rates by school

\begin{tabular}{lcccccc}
\hline \multicolumn{1}{c}{ School } & Rural Area & Urban Area & $\begin{array}{c}\text { Mann- } \\
\text { Whitney's }\end{array}$ & P-value \\
& $\bar{\chi}$ & Mdn & $\bar{\chi}$ & Mdn & U & \\
\hline Self-Consistency & 63.86 & 64.81 & 62.54 & 62.96 & 7934.00 & .44 \\
Self-Efficacy & 55.31 & 48.95 & 48.96 & 37.50 & 7315.00 & .10 \\
\hline Source: SCS and SCA & & & & & \\
$n=359$ & & & & & & \\
\end{tabular}

Table 5 indicates that students from rural schools present higher means and medians for selfconsistency and perceived self-efficacy than students from urban schools. Nevertheless, this difference is not enough for statistical significance.

\section{DISCUSSION}

This study allowed for the empirical verification of the main concepts of self-esteem, perceived self-efficacy and consumption of alcohol and tobacco. Participants were 56 students from a rural secondary school and 303 students from an urban secondary school.

Regarding the adolescents' characteristics, a higher number of students from the rural secondary school study and work as assistants or employees when compared to urban students. The fact that they have to work is probable due to the poverty conditions ofrural areas in Mexico. As a result, these adolescents feel the need to contribute to the maintenance of their family.

The initial age for alcohol consumption is similar for students from both urban and rural schools, i.e. 11 years old. Likewise, the beginning of tobacco consumption happens one year later, when they are 12 , in students from both urban and rural schools. Such findings are similar to what is reported by CONADIC ${ }^{(7)}$, which shows a tendency to anticipate the start of consumption of these substances in Mexican students from rural and urban areas. 
With regard to the global prevalence of tobacco consumption (once in a lifetime), lapsed prevalence (in the last 30 days) and instantaneous prevalence (in the last seven days), the study observed major proportions for the three prevalence measures in tobacco consumption of by students from the urban secondary school (35\%, 10\% and $4.6 \%$ respectively) than by students from the rural area. However, these three prevalence measures for alcohol consumption were higher in the rural $(23.2 \%, 14.3 \%$ and $1.8 \%$ respectively) than in the urban area, except for instantaneous prevalence $(18.8 \%, 6.6 \%$ and $3.3 \%$ respectively). The data reported in the present study concerning the three alcohol prevalence measures indicate that they are inferior to the national average, according to CONADIC ${ }^{(7)}$

Significant differences regarding tobacco consumption by adolescents, who study in urban and rural areas, were observed in the first objective $(U=7513.50, p=.03)$. It indicated that the consumption is higher in students in the urban $(\bar{\chi}=.35)$ than in the rural area $(\bar{\chi}=.14)$. No significant differences were found in alcohol consumption, although it was found higher in the urban area. These findings are probably due to the fact that young people from urban areas are more exposed to advertisements of those products through mass communication means. Besides, one of the limitations for young people from rural areas is their economic status, which complicates the acquisition of those products. Also, the fact that they live in small populations certainly allows the parents of these adolescents to supervise their children's behavior better.

The second objective showed a negative and significant association between self-esteem (selfconsistency) and the quantity of drinks and cigarettes consumed on a typical day by the students from both rural and urban schools $\left(r_{s}=-.23, p<.005 ; r_{s}=.20\right.$, $p<.001$, respectively). This information is similar to other research ${ }^{(10)}$, as self-consistency (self-esteem) is associated to student behavior in the decision to avoid the use of addictive substances like alcohol and tobacco.

Indications of the third objective regarding perceived self-efficacy and the quantity of drinks and cigarettes consumed on a typical day by students from both urban and rural schools did not present a significant association. Those findings go against what is conceptually indicated by those who defined selfefficacy of resistance as a factor that enables the person to resist to the temptation of consuming addictive substances ${ }^{(11)}$. This finding is probably explained by the fact that students who study in secondary schools from both urban and rural areas reported very low averages of self-efficacy, which indicates that both groups are exposed to multiple tempting situations to consume tobacco and alcohol, and they admit little abilities of self-efficacy to resist to such temptations.

Also in the third objective, the study considered the relation between the initial age of alcohol and tobacco consumption and students' selfesteem (self-consistency) and perceived self-efficacy abilities in the rural school, separately from the urban school, which did not show significant relations. Nevertheless, significant and negative relations between the quantity of drinks consumed on a typical day and self-esteem (self-consistency) and selfefficacy were only found in students from the urban schools, similarly to what is conceptually established $^{(11)}$. Moreover, young people from urban areas, probably have assertiveness and other social abilities that may be developed in the urban context, which help them refuse consumption even if their perceived self-efficacy is lower than in adolescents from the rural area.

Finally, the differences in self-esteem (selfconsistency) and self-efficacy in adolescents who study in urban and rural secondary schools were not significant to respond to the fourth objective. Even though there were higher means and medians in the rural area, they were found low in both cases. Such finding is probably a result of the education systems and the context the adolescents live in, which is not reinforcing the essential social skills needed for the students' complete development.

Furthermore, the study also observed that students who do not consume tobacco and alcohol reported higher averages of self-esteem (selfconsistency) $(\bar{\chi}=64.26)$ than those who consume both substances $(\bar{\chi}=52.46)$. Such difference was considered significant and similar to what is conceptually suggested ${ }^{(10,17)}$, which evidences that the value judgment the subjects have about themselves will affect their behavior or permit the development of healthier lifestyles. Therefore, it is important to assume that educational intervention programs enable students not only for the prevention of alcohol and tobacco, but also increase their self-esteem and favoring the prevention of other risk behaviors ${ }^{(18)}$. 


\section{CONCLUSIONS}

Tobacco consumption was found significantly different between students from secondary urban and rural schools, presenting higher rates in the urban area. However, alcohol consumption did not present substantial differences in adolescents from both schools, even though it was higher in students from the urban area.

The observation of the quantity of drinks and cigarettes consumed on a typical day and the selfesteem (self-consistency) of students from both areas found an inverse relation between them, in which the lower the alcohol and tobacco consumption, the higher the self-esteem. The study did not find any relation between the quantity of drinks and cigarettes consumed on a typical day and the perceived selfefficacy in students from both schools.

Likewise, no substantial difference was found in the self-esteem and perceived self-efficacy of students from both areas. Nevertheless, lower levels were found for students from the urban area.

Adolescents who study in urban and rural secondary schools and do not consume any tobacco or alcohol presented higher self-esteem (self- consistency) than those who consume either one of the substances or both.

The internal consistency of the instruments used in the study development, such as the selfconsistency instrument SCS and the scale of selfefficacy in students, to resist to the consumption of alcohol and tobacco, were considered acceptable.

\section{ACKNOWLEDGEMENTS}

Acknowledgements to the Inter-American Drug Abuse Control Commission/CICAD of the SubSecretary of Multidimensional Security at the Organization of American States/OAS, the Brazilian Anti-Drugs Secretary/SENAD, faculty members at the University of São Paulo at Ribeirão Preto College of Nursing, WHO Collaborating Centre for Nursing Research Development, Brazil, to the population who participated in the studies and to the representatives from eight Latin-American countries who participated in the I and II On-Line Specialization Program for Research Capacity-Building on the Drugs Phenomenon-PREINVEST, offered in 2005/2006 by the University of São Paulo at Ribeirão Preto College of Nursing, as a distance education course.

\section{REFERENCES}

1. Instituto Nacional de Estadística Geografía e Informática [INEGI]. Principales causas de mortalidad general, Estadísticas vitales. México, 2001.

2. Centers for Disease Control. Centers for Disease Control: Cigarette Smoking Among Adults-United States, 2000. Morbidity Mortality Weekly Rep. 2002; (45):588-90.

3. Secretaría de Salud (MX). Dirección General de Información en Salud. Sistema Nacional de Estadísticas Vitales. México; 2004.

4. Harrison P, Fulkerson J, Park E. The relative importance of socialversus commercial sources in youth access to tobacco, alcohol and other drugs. Preventive Med 2000; (31): 39-48. 5. Bandura A. The explanatory and predictive scope of selfefficacy theory. J Soc Clin Psychol 1986; 4(3): 359-73.

6. Secretaría de Salud (MX). Consejo Nacional Contra las Adicciones. El Consumo de drogas en México: Diagnóstico, Tendencias y Acciones. México; 1999.

7. Secretaria de Salud (MX). Consejo Nacional Contra las Adicciones. Encuesta Nacional de Adicciones 2002 del tabaco, alcohol y otras drogas. México; 2003.

8. Duncan SC, Duncan TE, Hops H. Progressions of alcohol, cigarette and marijuana use in adolescents. J Behav Med 1999; 21 (4): 375-88.

9. Secretaria de Salud (MX). Norma Oficial Mexicana NOMSSA2-1999, para la Prevención, Tratamiento, y Control de las Adicciones. México: Secretaria de Salud; 2000.
10. Zhan L. Cognitive Adaptation and self-Consistency in hearing-Impaired Older Persons: Testing Roy's Adaptation Model. Nurs Sci Q 1999; 13(2): 158-65.

11. Bandura A. Autoeficacia: Cómo afrontamos los cambios de la sociedad actual. Bilbao, España: Ed. Descleé de Broker; 1999.

12. Skutle A. The relationship among self- efficacy expectancies, severity of alcohol abuse, and psychological benefits from drinking. Addictive Beh 1999; 24(1): 87-98.

13. Becoña I. Factores de riesgo y Protección. Bases teóricas que sustentan los programas de prevención de drogas: Plan Nacional de drogas. España: Universidad de Santiago de Compostela; 1999.

14. López GT, Moreno JB. La Depresión y Autoestima como Predictores de Comportamientos de altos riesgos. Madrid; Universidad Autónoma de Madrid; 2002.

15. Annis HM, Grahanm J. Situational Confidence Questionnaire Addiction Research Foundation. Toronto, Canada; 1987.

16. Secretaría de Salud (MX). Reglamento de la Ley General de Salud en materia de investigación para la salud. Mexico; 1987.

17. Rosenberg M. Society and the Adolescents Self Image. Meddletown, CT: Welwyan Univerity Press, 1989.

18. Almanza SEE, Pillon SC. Programa para fortalecer factores protectores que limitan el consumo de tabaco y alcohol en estudiantes de educación media. Rev Latino-am Enferm 2004 março-abril 12(número especial): 324-32. 